DOI: https://doi.org/10.12962/j26139960.v6i1.103 $\quad$ Naskah Masuk 18-08-2021; $\quad$ Naskah Diulas 01-12-2021; $\quad$ Naskah Diterima 14-12-2021

NASKAH ORISINAL

\title{
Pengembangan Layanan Bisnis Digital Selam Rekreasional dengan Pendekatan ROPO pada UMKM Penyedia Jasa Selam
}

\author{
Ika Nurkasanah $^{1,{ }^{*}}$ | Rully Agus Hendrawan ${ }^{1}$ | Mudjahidin $^{1}$ | Erma Suryani ${ }^{1}$ | Mahendrawathi \\ $E^{1}$ | Andre Parvian Aristio ${ }^{1}$
}

\footnotetext{
${ }^{1}$ Departemen Sistem Informasi, Institut Teknologi Sepuluh Nopember, Surabaya, Indonesia
}

\section{Korespondensi}

*Ika Nurkasanah, Departemen Sistem Informasi, Institut Teknologi Sepuluh Nopember, Surabaya, Indonesia. Alamat e-mail: ika.nurkasanah@its.ac.id

\footnotetext{
Alamat

Laboratorium Sistem Enterprise, Departemen Sistem Informasi, Fakultas Teknologi Elektro dan Informatika Cerdas, Institut Teknologi Sepuluh Nopember, Surabaya, Indonesia
}

\begin{abstract}
Abstrak
Dalam kondisi ekonomi yang terpuruk akibat pandemi COVID-19 ini, Usaha Mikro, Kecil, dan Menengah (UMKM) memiliki potensi yang sangat besar untuk membantu membangkitkan perekonomian. Salah satunya adalah UMKM di bidang pariwisata jasa selam. Namun, selama ini peminat selam rekreasional masih cukup rendah karena tidak semua orang mengetahui keindahan bawah laut. Oleh karena itu, dalam program pengabdian masyarakat ini kami mengembangkan layanan bisnis digital berbasis website untuk mempromosikan keindahan wisata selam melalui pendekatan ROPO (Research Online Purchase Offline). ROPO dipilih sebagai pendekatan yang tepat karena di era digital dan pandemi masyarakat memiliki kecenderungan untuk melakukan riset online terlebih dahulu agar mendapatkan informasi lengkap dan terpusat sebelum melakukan pembelian produk/jasa secara luring. Tahapan program pengabdian masyarakat diawali dengan analisis kebutuhan mitra yang kemudian dilanjutkan dengan beberapa tahap lain, seperti desain arsitektur website, pengembangan website, uji coba website, implementasi (go live), dan yang terakhir soft launching kepada mitra dan pengguna. Hasil pengabdian masyarakat ini mampu memberikan kemudahan bagi para UMKM penyedia selam rekreasional untuk melakukan pemasaran online, memperluas wilayah pemasarannya, dan meningkatkan kredibilitas layanan bisnisnya. Bagi calon penyelam, website memudahkan pencarian informasi wisata selam sebelum pembelian dilakukan langsung, Selain itu, fitur dive log mampu memotivasi pengguna lain untuk menyelam melalui pengalaman yang dibagi.
\end{abstract}

\section{Kata Kunci:}

Pariwisata, UMKM Selam Rekreasional, Bisnis Digital, Research Online Purchase Offline, Economic Growth. 


\section{1 | PENDAHULUAN}

\section{1 | Latar Belakang}

UMKM atau Usaha Mikro, Kecil, dan Menengah menjadi salah satu saksi sejarah ketika Indonesia mengalami krisis ekonomi pada tahun 1997. UMKM mempunyai peran yang sangat penting dalam roda perekonomian negara. UMKM terbukti mampu untuk memberikan dampak signifikan terhadap pertumbuhan ekonomi negara. Pemerintah berulang kali mengeluarkan kebijakan yang mendorong perkembangan UMKM untuk menjadi roda penggerak perekonomian terutama ekonomi mengengah kebawah. Dan terbukti berdasarkan data yang dihimpun Badan Pusat Statistik (BPS) jumlah UMKM di Indonesia terus mengalami perkembangan yang signifikan selama tahun 2015, 2016, dan $2017^{11}$.

Dalam kondisi ekonomi akibat pandemi COVID-19 ini, UMKM merupakan salah satu sektor yang terdampak krisis ekonomi, termasuk UMKM di bidang pariwisata. Ketakutan masyarakat untuk keluar rumah, aturan dari pemerintah yang membatasi kegiatan, maupun wisatawan asing yang tidak bisa datang ke Indonesia untuk berwisata. Hal-hal tersebut menyebabkan pelanggan di sektor pariwisata menjadi turun drastis.

Menurut Pusat Data dan Sistem Informasi Kemenparekraf, kunjungan wisatawan mancanegara ke Indonesia melalui seluruh pintu masuk bulan Januari 2021 berjumlah 141.264 kunjungan atau mengalami penurunan sebesar -89,05\% dibandingkan bulan Januari 2020 yang berjumlah 1.290.411 kunjungan [2]. Begitu juga dengan jumlah wisatawan manca negara ke Provinsi Bali pada bulan Agustus 2020 mengalami penurunan sedalam -53,19 persen dibandingkan dengan catatan bulan Juli 2020. Bila dibandingkan dengan bulan Agustus 2019, jumlah wisawatawan ke Bali tercatat turun hampir 100 persen yaitu sekitar $-99,996$ persen ${ }^{[3]}$.

Penurunan ini juga terjadi pada mitra kami yaitu Surabaya Diving yang merupakan UMKM penyedia jasa pelatihan menyelam yang di Surabaya. Surabaya Diving juga sudah terkualifikasi untuk memberikan fasilitas sertifikasi diving seperti Open Water hingga tingkat profesional seperti Dive Master. Selain sertifikasi, Surabaya Diving juga menyediakan beberapa layanan perjalanan selam rekreasional seperti ke Labuan Bajo dan Raja Ampat. Beberapa permasalahan yang muncul seperti kurangnya pemahaman pemilik mengenai detail informasi yang harus ditampilkan dan diperbaharui pada website. Sementara masyarakat sebagai pelanggan potensial masih belum mengenal platform yang dapat mengenalkan dan memberikan informasi detail seputar wisata selam.

Oleh karena itu, dalam pengabdian masyarakat ini tim penulis membangun solusi berupa website layanan bisnis digital selam rekreasional dengan pendekatan ROPO (Research Online Purchase Offline) yang memberikan berbagai informasi komprehensif terkait lokasi selam, keindahan bawah laut, dan sertifikasi yang dibutuhkan di Indonesia. Selain itu, website ini juga akan menghubungkan masyarakat dengan UMKM penyedia jasa selam. Dengan adanya website ini diharapkan mampu meningkatkan minat berwisata selam di masyarakat dan membantu pemasaran dari UMKM penyedia jasa selam sehingga dapat membangkitkan perekonomian Indonesia di tengah pandemi Covid-19 ini.

\section{2 | Tujuan, Manfaat, dan Dampak Kegiatan yang Diharapkan}

Tujuan dari kegiatan ini adalah untuk menyediakan informasi yang terstruktur sesuai dengan kebutuhan pelanggan dan mengembangkan situs web sebagai narahubung digital tambahan untuk sarana memasarkan produk/layanan UMKM penyedia jasa selam.

Sejauh ini pelanggan dari Surabaya Diving hanya terbatas pada lokasi Surabaya dan sekitarnya. Sehingga, terciptanya website ini diharapkan memudahkan pemasaran layanan oleh mitra UMKM secara luas melalui media online dengan berbagai informasi yang lengkap dan terpusat sehingga dapat meningkatkan volume penjualan UMKM. Sedangkan bagi pengunjung, website dapat meningkatkan minat dan pengetahuan masyarakat terkait wisata selam dan mempercepat keputusan untuk membeli layanan. Hal tersebut didukung dengan tampilan informasi yang efektif dan terstruktur seperti titik lokasi selam, berbagai biota dalam suatu dive spot, dan menampilkan UKM penyedia layanan wisata selam untuk spot tersebut. Selain itu, website juga dapat memotivasi pengunjung potensial untuk saling berbagi pengalaman wisata selam yang pernah dilakukan.

Dampak kegiatan yang diharapkan dari pengembangan website ini antara lain: 1) memberikan kemudahan bagi setiap orang/pengguna dalam mencari informasi produk UMKM penyedia jasa selam, 2) memberikan kemudahan bagi para UMKM 
yang kesulitan dalam memasarkan produknya secara daring (online), dan 3) memungkinkan penjualan yang dapat mencakup area yang lebih luas, sehingga mampu menaikkan volume penjualan.

\section{2 | TINJAUAN PUSTAKA}

\section{1 | Pentingnya Bisnis Digital Bagi UMKM}

Digitalisasi dalam bisnis memungkinkan pelaku bisnis untuk memanfaatkan teknologi digital dalam kegiatannya. Adanya digitalisasi serta perkembangan pesat dalam teknologi membawa dampak yang besar dalam aspek ekonomi ${ }^{4}$. Teknologi digital dapat dengan mudah menghubungkan pelaku bisnis dengan para calon pelanggan mereka. Bisnis digital penting bagi UMKM untuk memperluas jangkauan usaha mereka, sehingga dapat memajukan bisnis dan meningkatkan profit. Apalagi ada banyak UMKM yang terkena dampak virus Covid-19 bahkan ada yang sampai menutup usaha mereka ${ }^{[5}$. Sehingga, agar dapat tetap bertahan dan mampu bersaing, industri UMKM harus dapat memanfaatkan teknologi untuk keberlanjutan bisnisnya.

Salah satu UMKM selam rekreasional yang tengah menjadi mitra dalam kegiatan pengabdian masyarakat, yakni Surabaya Diving mengalami penurunan pelanggan akibat dampak pandemi. Proses pemasaran eksisting mereka cenderung memanfaatkan penyebaran informasi dari mulut ke mulut membuat jangkauan hanya terbatas pada lingkup tertentu saja, yaitu lokasi Surabaya dan sekitarnya. Maka dari itu, perlu adanya perluasan lingkup jangkauan pelanggan dengan memanfaatkan digitalisasi bisnis.

\section{2 | Research Online, Purchase Offline}

Research Online, Purchase Offline (ROPO) adalah pendekatan bisnis digital yang melibatkan pencarian oleh pelanggan, informasi yang mendalam tentang produk melalui internet, namun selanjutnya pembelian dilakukan dalam bentuk tradisional, yaitu datang langsung ke toko konvensional ${ }^{6}$. Perkembangan teknologi telah berkontribusi pada layanan online yang lebih canggih yang mendukung elemen individual dari proses pembelian, serta kemudahan dalam mencari informasi yang tersedia di internet menyebabkan calon pelanggan sering menggunakan media ini sebagai sumber informasi utama ${ }^{[7}$. Calon pelanggan bisa memanfaatkan blog, video, atau ulasan singkat mengenai suatu produk sebelum memutuskan untuk melakukan pembelian.

Penyelam rekreasional perlu memperhatikan banyak hal sebelum melakukan aktivitas menyelam, mulai dari persyaratan, peralatan, waktu penyelaman, hingga lokasinya. Hal tersebut membuat setiap calon penyelam perlu mengumpulkan banyak informasi sebagai pertimbangan kelanjutan aktivitasnya. Salah satu kelebihan dari konsep ROPO adalah dapat memberikan kemudahan bagi calon pembeli untuk membandingkan harga dan fitur berdasarkan ulasan informasi pada situs website ${ }^{[8]}$ ini dapat meyakinkan mereka untuk melanjutkan akivitas hingga proses pembelian produk. Selain itu, hal ini juga memberikan keuntungan bagi penyedia bisnis dalam memasarkan produknya.

Berdasarkan penelitian oleh IBI atau University Regensburg, menunjukkan bahwa lebih dari 80 persen orang cenderung mencari informasi di internet terlebih dahulu sebelum memutuskan membeli produk ${ }^{\sqrt{9}}$. Selain itu, studi terhadap penerapan metode ROPO pada industri fashion menunjukkan hasil evaluasi secara keseluruhan dari dampak informasi yang ditemukan di internet untuk membuat keputusan pembelian menegaskan bahwa terjadi peningkatan sistematis dalam popularitas e-commerce

pada industri pakaian ${ }^{10}$. Keunggulan dari pendekatan ROPO tersebut mendorong kegiatan pengabdian masyarakat ini untuk mengadopsi konsep tersebut dalam pengembangan layanan bisnis digital pada selam rekreasional.

\section{3 | Gambaran Kondisi Mitra}

Surabaya Diving merupakan UMKM penyedia jasa pelatihan menyelam yang berada di Surabaya yang memiliki instruktur sekaligus pemilik dengan pengalaman mengajar lebih dari sepuluh tahun dan memegang predikat sebagai SSI Platinum 1000 Instructor. Dengan predikat tersebut, Surabaya Diving terkualifikasi secara baik untuk mengajarkan berbagai macam tingkatan dalam menyelam, mulai dari Open Water yang merupakan tingkatan pertama sebagai penyelam pemula hingga Dive Master untuk level profesional.

Surabaya Diving juga menyediakan layanan dive trip dengan tujuan beberapa diving spots yang sudah terkenal keindahannya di Indonesia, seperti Pantai Pasir Putih Situbondo, Pulau Menjangan, Labuan Bajo, dan Raja Ampat. Untuk layanan dive trip ini tidak selalu dilakukan di tempat-tempat yang disebutkan sebelumnya, karena Surabaya Diving cenderung menawarkan layanan ini sesuai permintaan dari pelanggan baik secara berkelompok maupun individu. 
Selain sebagai penyedia jasa pelatihan menyelam, Surabaya Diving juga memiliki komunitas bagi orang-orang yang memiliki hobi menyelam di Surabaya dan sekitarnya. Komunitas ini memiliki cukup banyak kegiatan yang bermanfaat bagi lingkungan sekitar, seperti kegiatan amal, memberikan bantuan ke korban bencana, kegiatan membersihkan pesisir laut, dan masih banyak lagi. Melalui komunitas ini pula Surabaya Diving sering mendapatkan pelanggan, yaitu dengan promosi dari mulut ke mulut anggotanya.

Sebelum adanya pandemi, dalam kondisi normal setiap bulannya selalu ada pelanggan yang mendaftar untuk sertifikasi menyelam, dan setiap minggunya bisa melakukan dive trip ke laut. Namun, karena adanya pandemi dan kebijakan PSBB, maka kegiatan latihan maupun dive trip menjadi tertunda dan dive center tidak bisa beroperasi seperti biasanya.

Ini menjadi sesuatu hal yang disayangkan karena Surabaya Diving berpotensi untuk melebarkan usahanya dengan menarik lebih banyak pelanggan lagi, terlebih Surabaya Diving telah memiliki citra yang positif sehingga banyak dari murid atau diver yang pernah belajar dan mengikuti dive trip merekomendasikan Surabaya Diving kepada kenalan atau koleganya untuk belajar atau mengikuti dive trip di Surabaya Diving. Jika dibantu dengan adanya digitalisasi bisnis maka pemasaran dan penyebaran informasi tentang Surabaya Diving menjadi lebih mudah dan efisien. Pemasaran digital juga efektif sebab menyasar pada target pasar yang tepat dan jangkauan konsumen menjadi lebih luas lagi.

\section{3 | STRATEGI KEGIATAN}

Dalam pengembangan layanan bisnis digital untuk UMKM selam rekreasional ini ada beberapa strategi kegiatan yang diterapkan oleh tim pengabdi masyarakat. Pertama, menentukan target pengabdian masyarakat yaitu para UMKM penyedia jasa selam di wilayah Surabaya dan sekitarnya, khususnya Surabaya Diving. Para UMKM selam tersebut cenderung melakukan penjualan bisnisnya secara offline dan pemasarannya masih terbatas dalam lingkup tertentu. Maka dari itu, dengan memanfaatkan penerapan konsep ROPO dalam bisnis digital mereka, maka UMKM akan mendapatkan akses pasar yang lebih luas dan meningkatkan peluang untuk mendapat pelanggan baru hingga akhirnya mendapatkan profit yang lebih besar. Sementara itu, calon pelanggan juga akan lebih mudah dalam proses mendapatkan informasi yang diperlukan secara online.

Dalam pengembangan website dengan konsep ROPO, tim telah mempertimbangkan kebutuhan calon pelanggan sebagai pengguna akhir dari website melalui iterasi wawancara terhadap calon pelanggan potensial. Selanjutnya, implementasi dari website ini dimulai dari perancangan desain website agar sesuai juga dengan kebutuhan dari mitra. Sebelum meluncurkan website, domain dan hosting yang tepat dipilih terlebih dahulu. Selain itu, agar pengguna dapat menggunakan website yang ada dengan baik dan lancar, telah dilakukan sosialisasi website (soft launching) kepada mitra khususnya Surabaya Diving agar dapat menjalankan website tersebut dengan lancar. Dalam sesi akhir sosialisasi tersebut akan diperoleh feedback dari pengguna dan mitra agar dapat digunakan sebagai evaluasi pengembangan kedepannya.

\section{4 | METODE PELAKSANAAN}

\section{1 | Metode Kegiatan}

Metode yang diterapkan dalam kegiatan program pengabdian masyarakat ini dibagi menjadi 5 tahapan, diantaranya adalah sebagai berikut:

\section{Tahap Analisis Kebutuhan Mitra}

Pada tahap ini tim komunikator menghubungi mitra untuk membuat perjanjian serta kesepakatan terkait kesiapan mitra. Selain itu, tim juga mengumpulkan informasi mitra terkait permasalahan hingga informasi produk secara lengkap.

\section{Tahap Desain Arsitektur Website}

Saat tahap desain arsitektur berlangsung, kurator mencari informasi yang dibutuhkan melalui media internet ataupun meggunakan informasi yang didapat oleh komunikator saat bertemu mitra dan membuat skema database untuk menghasilkan Entity Relationship Diagram (ERD). Tim UX Designer kemudian membuat workflow dan sebuah tampilan interface dari website berupa prototipe untuk mempermudah pemahaman tester. 


\section{Tahap Pengembangan Website}

Tim Developer menentukan domain dan hosting, membangun database ke dalam server, serta membangun website menggunakan beberapa framework pada tahap ini.

\section{Tahap Uji Coba Website}

Tim Developer akan melakukan pengujian website secara whitebox untuk memastikan bahwa website terbebas dari kesalahan teknis program.

5. Tahap Implementasi Go Live (Sosialisasi dan Pendampingan)

Pada tahap terakhir ini, tim melakukan uji coba sekaligus sosialisasi (soft launching) kepada mitra dan 20 calon pengguna.

\section{2 | Organisasi Pelaksana}

Pelaksana kegiatan pengabdian masyarakat ini adalah dosen yang tergabung dalam laboratorium Sistem Enterprise Departemen Sistem Informasi ITS dan beberapa mahasiswa S1 Sistem Informasi ITS. Deskripsi dari masing-masing pembagian peran adalah sebagai berikut:

1. Ketua: berperan mengkoordinasi agenda kegiatan, rapat koordinasi, dan memantau capaian yang telah disepakati.

2. Tim Developer: membangun rancangan solusi menjadi implementasi berupa website hingga melakukan testing.

3. Tim UX: Membuat rancangan workflow solusi serta prototipe website, membuat rancangan desain website berdasarkan informasi yang telah dikumpulkan.

4. Tim Komunikator/Data: Mengumpulkan informasi yang dibutuhkan dalam pengembangan solusi dan membuat skema database.

Adapun pembagian peran masing-masing tim digambarkan melalui bagan pada Gambar 1

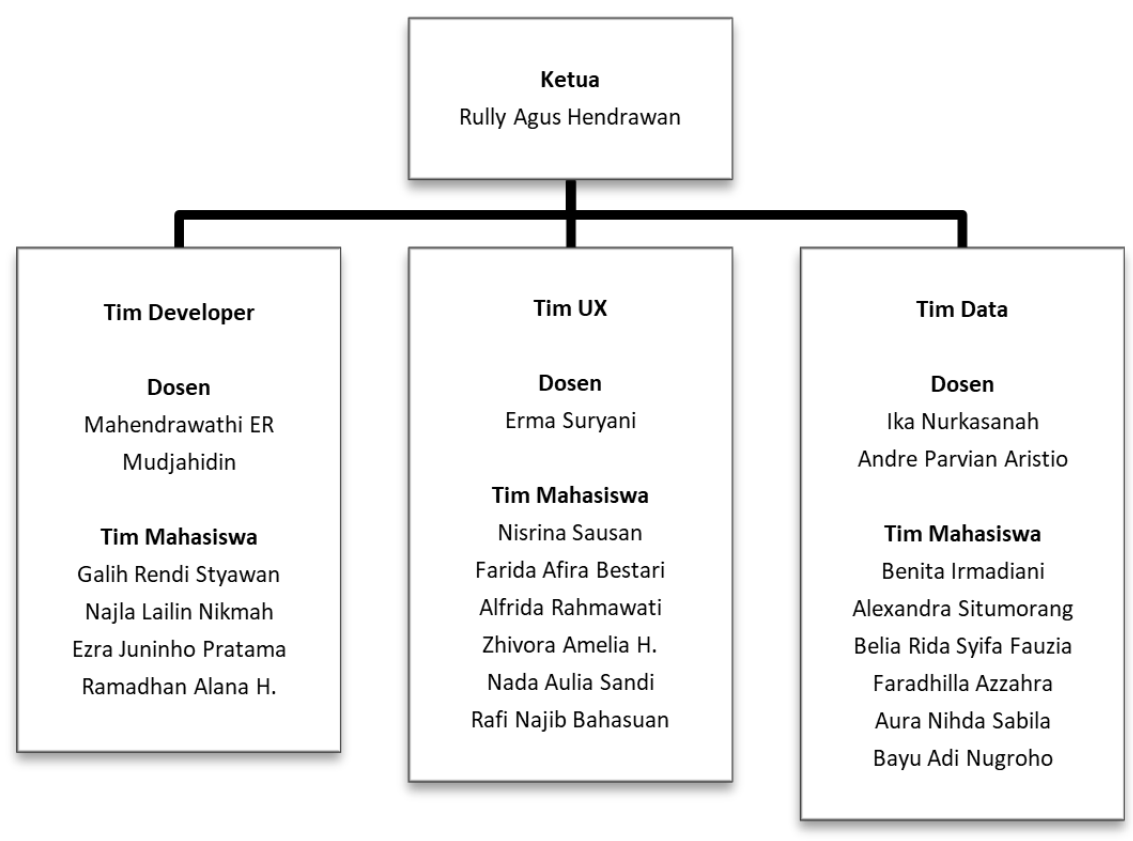

Gambar 1 Bagan organisasi pelaksana kegiatan. 


\section{5 | HASIL DAN PEMBAHASAN}

\section{1 | Analisis Adopsi Bisnis Digital dan ROPO}

Terdapat tiga bidang dimana pelaku bisnis dapat memanfaatkan teknologi digital baru, yaitu pengalaman pelanggan, proses operasional, dan model bisnis. Pengabdian masyarakat ini berfokus pada peningkatan layanan bisnis digital melalui rancangan pengalaman pelanggan yang memungkinkan pelaku bisnis untuk menerapkan digitalisasi informasi dan komunikasi untuk melibatkan pelanggan mereka dengan cara-cara baru 11$]$.

Website yang berhasil dikembangkan pada pengabdian masyarakat ini memungkinkan pelanggan usaha jasa selam untuk membangun komunitas pengguna (penyelam) dengan saling berbagi informasi secara online. Aktivitas berbagi informasi tersebut mulai dari pemberian informasi yang relevan dengan kebutuhan calon pengguna hingga pertukaran informasi dengan pengguna lainnya. Pengguna dapat membagikan informasi mengenai pengalamannya mulai dari foto ketika melakukan aktivitas diving, detil waktu pelaksanaan diving, peralatan yang mereka gunakan, hingga berbagai biota laut yang mereka temui ketika melakukan diving.

Dengan adanya proses pertukaran informasi antara pengguna satu dan pengguna yang lain memungkinkan mereka untuk membentuk suatu komunitas, sehingga dapat menambah nilai tambah website dibandingkan dengan website yang hanya menampilkan informasi tanpa melibatkan interaksi antar pengunjung website. Hal ini diharapkan mampu membantu calon pengguna lain untuk membuat keputusan terkait tujuan penyelaman dan destinasi tempat selamnya. Selain itu, fitur ini juga dapat membantu calon penyelam untuk mempersiapkan diri dan peralatannya sebelum membeli layanan secara offline dan melakukan kegiatan penyelaman. Dalam hal ini mitra juga akan diuntungkan karena bisnisnya dimuat dalam website yang komunitasnya akan terbentuk secara luas, sehingga memperbesar potensi kenaikan jumlah pelanggan.

Adopsi pendekatan ROPO pada website ini berupa proses pencarian informasi (research) yang komprehensif, terpusat, dan lengkap oleh pengunjung website atau pelanggan potensial. Ketika pengunjung sudah mendapatkan cukup informasi yang mereka butuhkan, mereka akan melakukan pembelian (purchase) dengan cara datang langsung ke tempat atau secara luar jaringan.

\section{2 | Hasil Pembuatan Website}

Rancangan arsitektur informasi pada penelitian ini dibuat berdasarkan studi literatur yang berkaitan. Tim pengembang terlebih dahulu memahami dasar dari permasalahan utama, yaitu kebutuhan akan informasi. Hal tersebut sesuai dengan hasil penelitian mengenai Information Behaviour ${ }^{[12]}$, yang bertujuan memahami bagaimana cara orang mencari dan menggunakan informasi dalam berbagai konteks. Mulai dari proses mencoba mendapatkan informasi dan proses pencarian informasi yang relevan dengan kebutuhan informasi. Sehingga, berikut merupakan beberapa halaman untuk website yang berhasil dibuat oleh tim.

\section{A Home}

Merupakan halaman awal yang ditampilkan saat pertama kali membuka web (Gambar 2). Terdapat navigation bar pada bagian atas beranda yang berisi navigasi menu-menu yang dapat di akses di web, seperti menu Dive Spot, Diver Logs, dan Home. Pada halaman ini juga ditampilkan rekomendasi spot diving dan juga Latest News seputar diving.

\section{B Dive Spot}

Halaman Dive Spot memuat detail informasi mengenai lokasi-lokasi menyelam yang dapat dikunjungi oleh pengguna. Halaman Dive Spot sendiri akan terbagi menjadi dua macam, yang pertama adalah halaman informasi yang menyebarkan informasi lokasi-lokasi dive spot yang ada di satu pulau, sedangkan halaman yang kedua akan memuat informasi mengenai detail-detail dari tiap dive spot tersebut (Gambar 3 .

\section{Diver's Log}

Merupakan halaman dengan fitur yang memungkinkan seorang diver yang sudah pernah melakukan diving pada suatu tempat untuk membagikan pengalaman diving-nya kepada pengguna lain. Seorang diver dapat membagikan berbagai macam informasi mengenai pengalamannya mulai dari foto ketika melakukan aktivitas diving, cerita mengenai pengalamanya menyelam, detil informasi mengenai waktu pelaksanaan diving, peralatan (gears) yang dibawa, kondisi alam pada 
saat itu (mulai dari suhu hingga kondisi ombak), biota alam yang ditemukan, dengan siapa ia melakukan diving, hingga memungkinkan pengguna lain untuk memberikan komentar terhadap dive log yang ditulis oleh diver tersebut. (Gambar 4.

\section{Diversity}

Diversity atau keanekaragaman adalah keindahan alam yang bisa ditemui ketika pengguna mengunjungi atau melakukan aktivitas pada lokasi diving tertentu. Diversity dapat ditemukan oleh pengguna ketika pengguna membuka halaman informasi dari dive spot. Informasi yang akan ditampilkan adalah hewan-hewan apa saja yang bisa ditemui pada lokasi tersebut yang diurutkan berdasarkan lokasi kedalaman dan probabilitas dari kemunculan hewan atau keanekaragaman yang ada. (Gambar 5

heaven for scuba divers

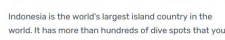

can explore w w

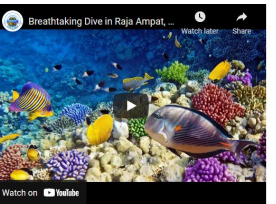

Gambar 2 Tampilan Halaman Home.

Dive Spots in Nusa Penida

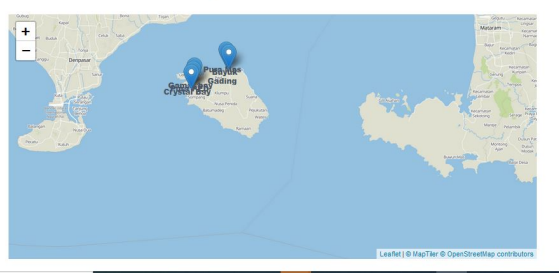

Gambar 3 Tampilan Halaman Dive Spot.

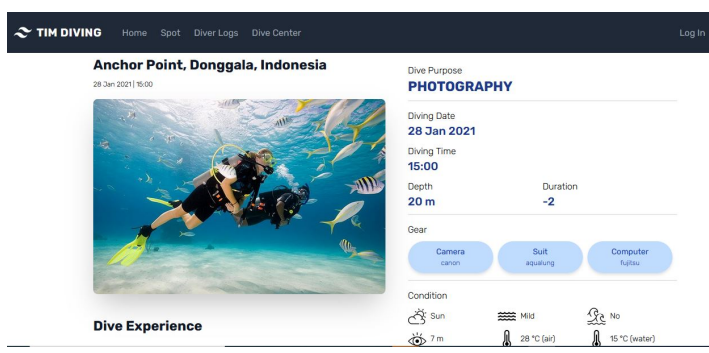

Gambar 4 Tampilan Halaman Diver's Log. 


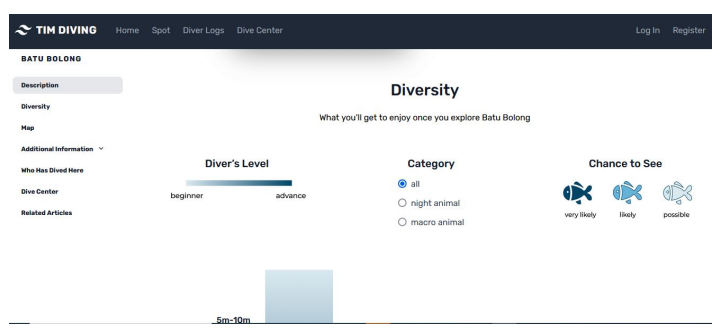

Gambar 5 Tampilan Halaman Diversity

\section{3 | Peningkatan Bisnis pada Mitra}

Melalui website selam rekreasional dengan konsep ROPO ini, peningkatan bisnis dapat dicapai baik oleh UMKM mitra maupun divers yang mengunjungi website, seperti terangkum pada Tabel 1 Bagi UMKM mitra, peningkatan bisnis yang dapat dicapai berupa kemudahan bagi para UMKM produk dan jasa layanan yang kesulitan dalam memasarkan produknya secara daring (online).

Tabel 1 Peningkatan Bisnis yang Dapat Dicapai

\begin{tabular}{|c|c|c|}
\hline Aspek & Sebelum adanya website & Sesudah Adanya website \\
\hline $\begin{array}{l}\text { Kemudahan } \\
\text { Pemasaran }\end{array}$ & $\begin{array}{l}\text { Pemasaran hanya dilakukan } \\
\text { dari mulut ke mulut }\end{array}$ & $\begin{array}{l}\text { Memberikan kemudahan bagi para UMKM produk dan jasa layanan } \\
\text { yang kesulitan dalam memasarkan produknya secara daring (online) } \\
\text { dengan informasi yang komprehensif. }\end{array}$ \\
\hline \multirow{3}{*}{$\begin{array}{l}\text { Transfer Knowledge } \\
\text { Ke pelanggan }\end{array}$} & $\begin{array}{l}\text { Pelanggan baru merupakan } \\
\text { kolega dari pelanggan lama }\end{array}$ & $\begin{array}{l}\text { Memungkinkan penjualan secara lebih luas, sehingga penjualan pun } \\
\text { dapat mencakup area yang lebih besar. }\end{array}$ \\
\hline & $\begin{array}{l}\text { Mitra harus menjelaskan } \\
\text { mengenai dive spot kepada } \\
\text { pelanggan atau pelanggan } \\
\text { harus mencari informasi } \\
\text { sendiri }\end{array}$ & $\begin{array}{l}\text { Website dengan konsep ROPO ini menyajikan informasi dive spot } \\
\text { secara lengkap }\end{array}$ \\
\hline & $\begin{array}{l}\text { Mitra menjelaskan banyak } \\
\text { hal mengenai diving gear } \\
\text { yang diperlukan }\end{array}$ & $\begin{array}{l}\text { Website memfasilitasi riset atau pencarian informasi dive gear yang } \\
\text { dilakukan oleh penyelam lainnya }\end{array}$ \\
\hline Kredibilitas Bisnis & $\begin{array}{l}\text { Testimoni biasanya ditulis di } \\
\text { akun sosial media pelanggan } \\
\text { sendiri }\end{array}$ & $\begin{array}{l}\text { Memberikan wadah untuk pelanggan menceritakan pengalamannya } \\
\text { mengenai layanan yang diberikan mitra }\end{array}$ \\
\hline
\end{tabular}

Mitra juga dapat memperluas jangkauan penjualan, dimana yang awalnya jangkauan penjualan hanya memanfaatkan promosi dari mulut ke mulut anggotanya. Selain itu, peningkatan bisnis yang dapat dicapai oleh UMKM mitra adalah penyajian informasi produk yang detil sehingga menunjang kredibilitas bisnisnya, termasuk melalui fitur untuk pelanggan menceritakan pengalamannya mengenai layanan yang diberikan mitra. Dengan lengkapnya informasi dan kemudahan pencarian dive gear, calon penyelam lainnya dapat melalukan riset atau pencarian informasi sehingga akan termotivasi untuk melakukan aktivitas selam rekreasional.

Dengan website ini, Surabaya Diving juga dapat menjangkau pelanggan yang berasal dari luar komunitasnya. Saat ini telah terbentuk komunitas penyelam dari 298 pengunjung website yang telah aktif (Gambar 6 .

Bagi para pengunjung website, proses bisnis yang dilakukan berkaitan dengan proses pencarian informasi. Pengunjung website ini terbagi menjadi dua jenis, yakni pengunjung website yang merupakan divers pemula dan berpengalaman. Bagi diver pemula mereka cenderung berkunjung untuk mencari informasi baik mengenai diving itu sendiri, dive spot, atau produk dan 


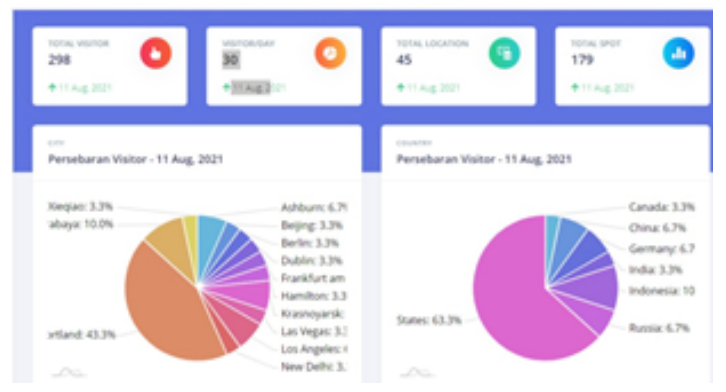

Gambar 6 Dashboard Pengunjung Website

layanan yang ditawarkan oleh mitra. Dengan berbagai informasi yang ditampilkan pada website, seperti pada halaman Beranda (Gambar 2, halaman Dive Spot yang menyajikan informasi untuk setiap titik penyelaman (Gambar 3 , dan Diversity yang memberikan informasi berbagai macam biota laut (Gambar 5 , pengunjung website bisa mempercepat pengambilan keputusan untuk melakukan pembelian. Dengan begitu, dapat sekaligus sebagai media promosi secara tidak langsung bagi UMKM mitra.

Sedangkan bagi pengunjung website yang merupakan divers berpengalaman, mereka dapat termotivasi untuk membagikan pengalaman mereka dalam melakukan penyelaman. Pengalaman yang mereka bagikan tidak sebatas narasi cerita yang dituangkan dalam komentar saja, melainkan juga informasi mengenai dive gear apa saja yang mereka gunakan, jarak pandang bawah laut, biota laut apa saja yang mereka temui pada saat menyelam pada dive spot tertentu, dan informasi penting lainnya yang membantu pengguna untuk melakukan riset secara online sebelum memutuskan membeli layanan secara langsung atau offline ke mitra. Aktivitas berbagi pengalamaan tersebut difasilitasi dengan baik melalui halaman Diver's Log (Gambar 4 pada website. Dengan adanya informasi yang penyelam lainnya bagikan, penyelam lain yang ingin melakukan penyelaman pada dive spot tersebut akan mendapatkan gambaran lebih dalam dan lebih mudah dalam melakukan persiapan.

\section{4 | Pembelajaran yang Diperoleh dari Pelaksanaan Program}

Selama pembuatan website, terdapat beberapa pembelajaran yang dapat menjadi pertimbangan untuk pengembangan selanjutnya, antara lain bahwa website ini sebaiknya bisa menggandeng lebih banyak mitra UMKM selam rekreasional dan lebih mengenalkan website ini ke komunitas diving yang berperan sebagai potential user. Dengan semakin banyaknya pengguna, maka semakin kaya juga informasi yang bisa didapatkan melalui website ini.

Selain itu, pembelajaran lain yang diperoleh dari pengembangan website ini adalah mitra UMKM selam rekreasional dapat sekaligus mempromosikan produk dan layanan mereka. Melalui salah satu tujuan yakni pemberian dukungan kredibilitas bisnis berupa adanya fitur review yang diberikan, pelanggan lainnya dapat mempertimbangkan kualitas produk yang ditawarkan mitra sebelum memutuskan untuk membeli.

\section{5 | Pengujian dan Pendampingan Penggunaan Website}

Pada tahap pengujian website kepada mitra dan potential users (Gambar 7 dan Gambar 8 , yaitu Surabaya Diving, tidak ada kesalahan sistem dan semua skenario fungsional telah berjalan lancar. Terdapat masukan dari mitra yang disampaikan saat pengujian, sosialisasi, dan pendampingan penggunaan website (Gambar 9, yaitu ada beberapa lokasi yang sebenarnya bagus dan menjual banyak diving spot namun masih belum ada di website, seperti Banda Neira (Maluku) dan Alor (NTT). Selain itu, beberapa spot yang ada di Raja Ampat juga sebenarnya masih ada yang bisa ditambahkan. Beberapa koreksi terminologi dalam konteks selam rekreasional juga telah disampaikan mitra dan telah diperbaiki oleh tim, seperti 1) purpose yang dapat diganti penamaannya dengan title, 2) informasi air mix yang perlu ditambahkan keterangan bahwa itu untuk tank diving, 3) mitra ternyata sangat antusias untuk mengoperasikan website dengan menambah informasi diving spots (Gambar 10 ), sehingga dalam kasus ini tim memberikan fasilitas halaman khusus untuk mitra. 


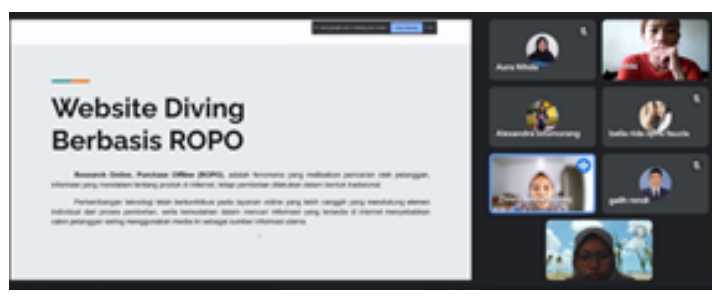

Gambar 7 Pengujian Website bersama Mitra

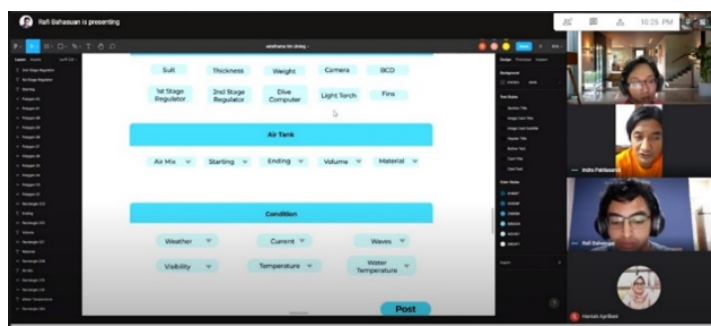

Gambar 8 Pengujian Website bersama Potential Users

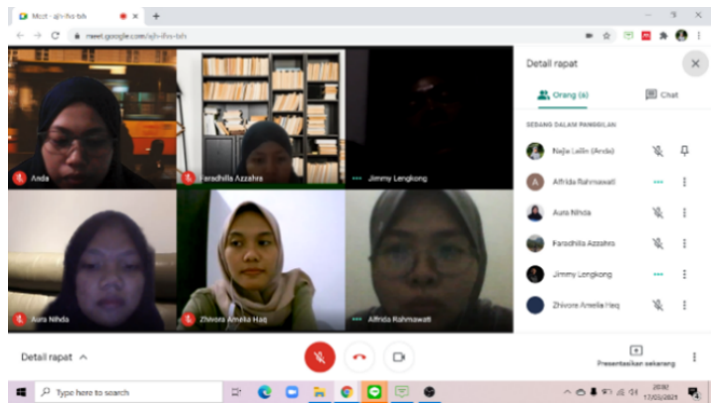

Gambar 9 Pendampingan Penggunaan Website

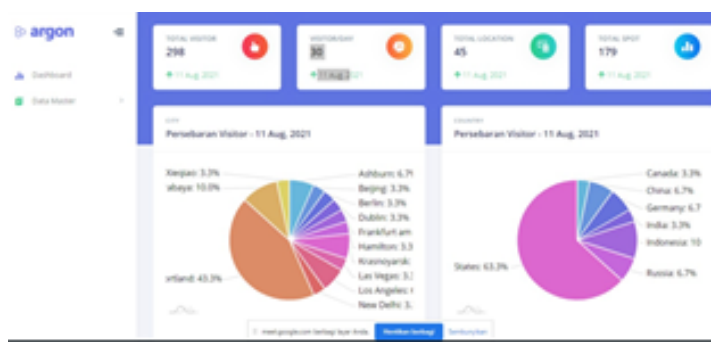

Gambar 10 Halaman penambahan informasi untuk mitra

\section{6 | Keberlanjutan Pengabdian Masyarakat}

Agar usaha selam rekreasional dapat mencapai pasar yang lebih luas dan perhatian penuh dari pengguna potensialnya, maka pihak penyedia jasa selam perlu memikirkan pentingnya pemanfaatan teknologi informasi tidak hanya digunakan sebagai sarana pemasaran, namun juga mendukung proses bisnisnya, yaitu desain layanan yang lebih berfokus pada pelanggan. Pada pengabdian masyarakat selanjutnya, adopsi website ini bisa menjadi masukan pihak mitra dalam menjamin kelancaran dan peningkatan 
proses bisnis. Pengembangan fitur diving log juga dapat ditingkatkan sehingga semakin membantu penyelam lainnya untuk mengatur ekspektasi pada lokasi selam yang akan dituju, keahlian / sertifikasi apa yang harus diminta, dan informasi penting lainnya yang ingin didapatkan atau malah mau dibagikan kepada pengguna lainnya.

\section{6 | KESIMPULAN}

Hasil pengembangan website diharapkan mampu menyelesaikan permasalahan berupa masih banyaknya masyarakat yang masih belum mengenal platform yang memberikan informasi detil seputar wisata selam. Salah satu fitur yang terdapat dalam website ini juga menggunakan pendekatan ROPO (Research Online Purchase Offline) dimana para pengguna dapat berinteraksi satu sama lain dan terhubung dengan UMKM penyedia jasa selam, sehingga dapat membantu pemasaran dari UMKM penyedia jasa selam. Saran untuk pengabdian masyarakat selanjutnya adalah penambahan fitur yang bisa menyajikan adanya peningkatan konversi dan penjualan mitra seperti fitur analytics untuk melihat banyaknya pengunjung dan produk atau jasa terlaris. Fitur analytics tersebut harapannya dapat mempermudah mitra dalam mengevaluasi bisnis. Pengabdian masyarakat selanjutnya juga diharapkan lebih melibatkan lebih banyak UMKM penyedia jasa selam rekreasional.

\section{7 | UCAPAN TERIMA KASIH}

Penulis mengucapkan terima kasih kepada Direktorat Riset dan Pengabdian Masyarakat Institut Teknologi Sepuluh Nopember yang telah memberikan dukungan melalui pendanaan dalam kegiatan pengabdian ini. Demikian juga kepada para partisipan yang bersedia meluangkan waktunya untuk memberikan umpan balik dalam kegiatan user testing mengenai website yang sedang penulis kembangkan, serta mitra UMKM jasa selam rekreasional Surabaya Diving yang bersedia memberikan segala informasi.

\section{Referensi}

1. Pribadi A, Ghozali K, Hidayanto BC, Hafidz I, Muqtadiroh FA, Al Hafidz M, et al. Pelatihan Teknik Social Media Marketing sebagai Sarana Pemasaran Produk pada Konveksi Kerudung 'Al-Kattar'Di Kelurahan Merjosari, Malang. SEWAGATI 2018;2(1).

2. Kemenparekraf PDdSI, Statistik Kunjungan Wisatawan Mancanegara 2021; https://www.kemenparekraf.go.id/ statistik-wisatawan-mancanegara/Statistik-Kunjungan-Wisatawan-Mancanegara-2021.

3. Bali BPSP, Perkembangan Pariwisata Provinsi Bali Agustus 2020;. https://bali.bps.go.id/pressrelease/2020/10/01/717333/ perkembangan-pariwisata-provinsi-bali-agustus-2020.html

4. Budiarta K, Ginting SO, Simarmata J. Ekonomi dan Bisnis Digital. Yayasan Kita Menulis; 2020.

5. Dwijayanti A, Pramesti P. Pemanfaatan Strategi Pemasaran Digital menggunakan E-Commerce dalam mempertahankan Bisnis UMKM Pempek4Beradek di masa Pandemi Covid-19. IKRA-ITH ABDIMAS 2021;4(2):68-73.

6. Szymanski G, Stanislawski R, et al. Research online-purchase offline-a phenomenon among the young generation in the e-commerce sector. Journal of International Scientific Publications 2018;12(1):185-192.

7. Szymanski G. Ropo effect in the food industry in women assessment ZU - UNIVERSITY OF ZILINA The Faculty of Operation and Economics of Transport and Communications. GLOBALIZATION AND ITS SOCIO-ECONOMIC CONSEQUENCES 17 th International Scientific Conference Rajecke Tep 2017;

8. Liubov Z. ROPO analysis: Why you need it and how to conduct it 2019:https://www.owox.com/blog/articles/ropo-effect/

9. Marcel V. Multi-Channel Study Highlights Importance of ROPO-Effect 2012:https://smarter-ecommerce.com/blog/en/ ecommerce/multi-channel-study-highlights-importance-of-ropo-effect/

10. Mróz-Gorgoń B, Szymański G. The impact of the ROPO effect in the clothing industry. Economics and Business Review 2018;4(3):24-35. 
11. Westerman G, Bonnet D, McAfee A. Leading digital: Turning technology into business transformation. Harvard Business Press; 2014.

12. Wilson TD. On user studies and information needs. Journal of documentation 1981;

Cara mengutip artikel ini: Nurkasanah, I., Hendrawan, R.A., Mudjahidin, Suryani, E., ER, M., Aristio, A.P., (2022), Pengembangan Layanan Bisnis Digital Selam Rekreasional dengan Pendekatan ROPO pada UMKM Penyedia Jasa Selam, Jurnal Sewagati, 6(1):28-39. 